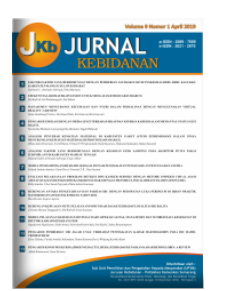

Volume 10 Nomor $1(2020)$ 14-18

JURNAL KEBIDANAN

p-ISSN: 2089-7669 ; e-ISSN: 2621-2870

https://dx.doi.org/10.31983/jkb.v10i1.5545

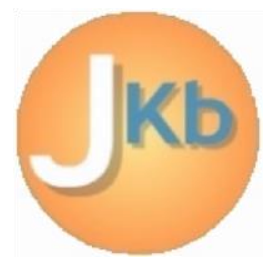

\title{
Supporting Factors of Sex Workers Behavior on HIV/AIDS Prevention:
} A Qualitative Study

\author{
Nurul Fadlila*, Hanifatur Rosyidah, Is Susiloningtyas \\ Faculty of Health Science, Department of Midwifery, Universitas Islam Sultan Agung \\ Jalan Raya Kaligawe Km.4 Semarang, 50112, Jawa Tengah, Indonesia \\ Corresponding author: Nurul Fadlila \\ Email: nurul.fadlila.nf@gmail.com
}

Received: January $24^{\text {th }}, 2020$; Revised: March $10^{\text {th }}, 2020$; Accepted: April $2^{\text {nd }}, 2020$

\begin{abstract}
As of November 2018, the number of HIV cases in Semarang reached up to 546. Sex workers have the highest risk to contract HIV/AIDS due to many sexual couples exposure. In 2018, the number of HIV in Argorejo location has increased three times compared to 2017. The purpose of the study was to describe the source of female sex workers information media to act in an effort to prevent HIV / AIDS in the Argorejo Localization in Semarang City. This study used descriptive qualitative method. Data collection techniques was in-depth interviews. Population in this research is female sex workers in the Argorejo Localization, Semarang City. A descriptive phenomenological study was used describe the experience of female sex workers during in prostitution. Eleven female sex workers, a foster mother also two health workers as data resource triangulation to collect the data. This analysis also uses content analysis. Most of the sex workers have heard of HIV/AIDS from magazine, social media, sign or poster in dorm and from friends. HIV/AIDS cases that have occurred to the sex workers' colleagues were one of the guides to behave or in other words considering the experience that has happened before is a strong predictor for behavior in the future.
\end{abstract}

Keywords : supporting factor; media information source; sex workers behavior; HIV/AIDS prevention

\section{Introduction}

Acquired Immunodeficiency Syndrome (AIDS) is the last stage of Human Immunodeficiency Virus (HIV) infection. After HIV infection evolves to AIDS, it will evoke a high infection risk. Without medication, HIV infection might evolve to AIDS due to a decreased immune system[1]. According to United Nations in HIV/AIDS program, approximately $32.2-38.8$ million people are infected with HIV in 2012. From that, approximately 3.4 millions are new cases.[2] Estimation of women sex workers in every regions in a world which affected HIV/AIDS are approximately $0.2 \%$ to $2.6 \%$ in Asia, $0.4 \%$ to $4.3 \%$ in Sub-Saharan Africa and $0.2 \%$ to $7.4 \%$ in Latin America.[3] HIV and AIDS are being a health challenge almost all over the world, especially in
Indonesia. As in October 2018, the number of HIV/AIDS patients are 305 people.[4]

Sexual intercourse with a good clinic manifestation based on gender or age will spread more than 30 kinds of pathogen. Aside from a sexual intercourse, sexually transmitted infections especially HIV can spread from the fetus in the womb or during childbirth. The media transmitted are through blood and medical devices.[5]

The causes of a high HIV/AIDS number in Semarang are due to a lot of nightclubs, prostitution, as what AIDS Commission of Semarang said[6]. Sex workers women have 13,5 times higher risk on getting HIV compared to nonsex workers women. United Commission shows that the effort to prevent HIV for sex workers is not quite effective, as a fact of high HIV prevalence.[2] 
Sex workers are the most group that can transmit HIV/AIDS and Sexually Transmitted Infections (STI). STI's issue is the biggest problem reflection in public health field in developing country. The factors that made someone becomes sex workers are poverty, sexual harassment such as rape, fraud (coercion under the guise of a work distribution agent), porn, luxurious life factor, broken home, economic, low intelligence and broken hearted.[7]

Health behavior is a person's response to stimuli related to illness and disease, the health care system, food and the environment. Stimuli related to health behavior consist of 4 elements, including: behavior towards illness and disease (health promotion behavior, health prevention behavior, health seeking behavior, and health rehabilitation behavior), behavior towards health service system, behavior towards food, behavior towards health environment.[8]

HIV and AIDS issues become health challenges almost in the world, especially in Indonesia. The numbers of HIV/AIDS patients as of October 2018 are 305.[4] According to HIV/AIDS development report from the Disease Prevention and Eradication, Division of the Semarang City Health Office, 546 cases are recorded as HIV patients until November 2018.[9]

Localization formation aims to alienate the general public especially children at puberty from the immoral influences of prostitution, facilitate supervision on female sex workers, prevent excessive extortion of female sex workers who are generally always the weakest party and facilitate mental guidance for female sex workers.[10]

Based on screening data from the Lebdosari Health Center, in 2018 the HIV rate in Argorejo localization has increased three times compared to 2017. From three in 2017, to ten in 2018 and April 2019.[11]

\section{Methods}

This study was exploring the female sex worker's experience during at prostitution, thus phenomenological approach used. The population in this study was female sex workers who come to the Voluntary Counselling Testing (VCT), was done by using in-depth interview technique from 11 sex workers, a foster mother and two health workers as work source triangulation. The method used as data analysis is content analysis. Researcher will conduct probing (inquiry/examination) by asking more detailed questions on the question points during interviews with informants to get more complete answers. Researcher observed research sites related to the behavior of WSW in HIV/AIDS prevention in Argorejo prostitution, Semarang. Data collection was done for 2 weeks, from the last week of July and early August 2019, located in Argorejo Prostitution, Semarang. This study uses three ethical principles, such as the principle of respecting human dignity (respect for person), the principle of doing good (beneficence) and not harming (non-maleficence), the principle of justice (justice).[12] This research has received Ethical Clearance from the Medical/Health Research Bioethics Commission of the Faculty of Medicine, Sultan Agung Islamic University, Semarang with Number 426/VII/2019/Bioethics Commission.

\section{Results and Discussion}

\section{Suporting Factors to Prevent HIV/AIDS}

a. Mass Media

In searching of HIV/AIDS information, a sex worker or informant usually get the information through printed media (newspaper, magazine, poster), search engine (Google), social media (Instagram) also they found condom use announcement in homestead wall. Other two informants said that they have never seen any HIV/AIDS information on mass media. One informant have only seen HIV/AIDS poster on the dorm wall. The information is accidentally found by them while they access information media. The following excerpts are the results of the interview:

"Poster Ma'am, especially in a World AIDS day, they are a lot of them."

(Sex Worker Informant 2)

"I think I saw "use condom" written outside of a dorm. That is why we use it when we are having sex."

(Sex Worker Informant 6)

"I think I found it on Instagram during a World AIDS day. It encourages us to use condom."

(Sex Worker Informant 8)

"There is a poster in a homestead."

(Sex Worker Informant 11)

b. Medical History from Family/Friends

Four sex workers informants stated that they have friends who are now HIV positive. Three informants know from their friends who have HIV/AIDS, even in last year, there was 1 person who died of HIV/AIDS, the same incident that also happened 4 years ago. However, there are two people who said that it might be from a friend at 
work, but they do not know who it was. Seven informants claimed that they did not have family or friends with HIV/AIDS.

"My friend is one of them, she was lived here but she passed away now."

(Sex worker Informant 1)

"There was a friend of mine who shared the same dorm with me, her name was Eka. Last year she passed away, poor her. Her body was getting skinnier. She often fell sick, coughed, and vomitted blood. Then, she got fired from here. No one accompanied her for checkup. She died on 2018."

(Sex worker informant 10)

"There was someone here who passed away due to HIV/AIDS, however, that person died while at home around four years ago."

(Sex worker informant 11)

In line with the information provided by sex worker informants, the key informant (foster mother) during an in-depth interview confirmed that there were indeed sex workers who had contracted HIV:

"The disease does not transmit through sweat. Therefore, indeed it will not be transmitted through exchanging clothes. For example, helping someone out there who got into accident, if we got injured and exposed to the blood of person with HIV then we will be infected as well. It will not happen if we eat together. Furthermore, if we drink through the same straw, and there are droplets of mucus on the straw, then it can be contagious. It is obviously can be transmitted through blood transfusion. If the patient is pregnant, then the baby also can be infected. There used to be a similar case here. She has passed SC, it's been a year. However, since she breastfed her child for a bit, the baby got infected with HIV. Now she already got married with a person from Semarang."

(Foster Mother Informant)

c. Information from Health Workers

All informants said that they also got information about HIV/AIDS prevention from health workers. Especially when Voluntary Counseling and Testing (VCT) is scheduled in the Argorejo resocialization Semarang. The following excerpts are the results of the interview:

"The information was given when there is an examination like this; some universities also gave us some outreach. That is how I get to know the transmission."

(Sex worker informant 1)

"Usually after VCT the health workers will explain.","

(Sex worker informant 10)
"The doctor inform us after examinations like this, or when there are some outreaches held.",

(Sex worker informant 11)

The foster mother also confirmed that she did give advice to all the sex workers under her care, especially in using condoms when having sexual intercourse and participating in VCT for early detection and treatment for HIV/AIDS:

"I've told them, 'Do you still want to stay here?", If you do, then you are required to participate in $V C T$ once in three months, screening once in three weeks if there is no problem, and once a week if there is a problem. If there is a problem and you need to be referred, then you are going to be referred. Use condom if you want to stay healthy. There are some who does not want to wear condom, those whose jobs are as a karaoke hostess or those who said, "'I only have sex with my partner, all healthy."

(Foster mother informant)

In this study the driving factor for the efforts to prevent HIV/AIDS is the source of information received by the sex workers. Media can affect aspects of human life such as electronic media, print media, health media and other media that provide information to the general public. A large number of more varied information is available, the information is increasingly scattered and widespread so that it can be easily accessed by the general public[13]. Not only from electronic and print media, the public can also obtain information from others such as teachers, family and peers[14].

The results showed that some sex workers had heard about HIV/AIDS from print media, social media, writing or posters at the dorm as well as from the experiences of the informants' friends. However, there are two informants who have never been exposed to information about HIV/AIDS from the mass media (electronic, print, social). Of all the informants, only four sex workers knew about additional HIV/AIDS information from their friends of the same profession who contracted HIV/AIDS, although it was not said how the disease was, but they saw firsthand how the symptoms were experienced by their friends. However, all informants received information about HIV/AIDS from health workers, especially during screening at Resocialization. Thus, this supporting factor is very influential on the behavior of sex workers in the efforts to prevent HIV/AIDS.

Which states that friends carry a great influence because there is a feeling of shared fate that makes them close to each other, and they have 
been together for a long period of time. The attention and advice given makes them feel relieved, happy, and comfortable so that they intend to carry out the behavior.[15]

Social support from peers in the form of a sense of shared fate makes a relationship of mutual apprehension and understanding each other's problems, giving each other advice, sympathy, which is not even obtained from their parents.[14] Learning from events or cases that have occurred is a valuable experience to learn in the future. This experience can be obtained from self and also from the surrounding environment. This is in accordance with the theory that states that learning is an experience that occurs within students that are activated by themselves.[16] According to the Health Belief Model theory, the driving factor in this case is a belief that causes a person to take preventive behavior towards disease. The belief comes from outside and from inside. Beliefs that come from outside such as mass media, advice from others, events occurred to family, friends or acquaintances, newspapers, magazine articles. Meanwhile, beliefs that come from within is the individual's perception of the state of his health.[14]

According to the researcher's assumption, if sex workers have a wrong perception of HIV/AIDS, wrong prevention behaviors will emerge. Information from closest relatives such as friends of the same profession actually brings a greater influence because learning from experience is more effective than reading. Network at work (for example, relationships with peers), have an influence on HIV/AIDS prevention. HIV/AIDS cases that have occurred in the sex workers' colleagues is one of the guides to behave or in other words consider the experience that has happened before which is a strong predictor for the behavior in the future.[17] The benefits they receive from the information they get are quite satisfying to them, from those who are unaware about something until they are aware about something even though sometimes their knowledge is still inaccurate and mixed with myths that had previously been held for advice or suggestions from the informant's relatives encourage the sex workers to conduct HIV/AIDS prevention measures most of the informants are still trapped in the myths that have developed in the community.[18]

This study has a limitation that does not involve supporting informants, such as guests or customers of CSW informants as a triangulation of additional sources to support researchers analyzing the factors that influence of female sex workers behavior in the prevention of HIV/AIDS.

\section{Conclusion}

HIV/AIDS cases that have occurred to sex workers' colleague is one of the guides to behave or in other words, considering the experience that has happened before is a strong predictor for the behavior in the future.

\section{References}

[1] E. P. F. Chow, A. E. Grulich, and C. K. Fairley, "Epidemiology And Prevention Of Sexually Transmitted Infections In Men Who Have Sex With Men At Risk Of HIV," Lancet HIV, vol. 0, no. 0, Apr. 2019, doi: 10.1016/S2352-3018(19)30043-8.

[2] N. C. Auli, C. Mejía-Lancheros, A. Berenguera, and E. Pujol-Ribera, "Risk Perception Of Sexually Transmitted Infections And HIV In Nigerian Commercial Sex Workers In Barcelona: A Qualitative Study," BMJ Open, vol. 5, no. 6, 2015, doi: 10.1136/bmjopen-2014-006928.

[3] E. V. Pitpitan, S. C. Kalichman, L. A. Eaton, S. A. Strathdee, and T. L. Patterson, "HIV/STI Risk Among Venue-Based Female Sex Workers Across The Globe: A Look Back And The Way Forward," vol. 10, no. 1, pp. 65-78, 2014, doi: 10.1007/s11904-012-01428.HIV/STI.

[4] Kementrian Kesehatan Republik Indonesia, "Kemenkes Jamin Ketersediaan ARV." Kemenkes RI, Jakarta, 2019.

[5] Kepmenkes RI, "Data dan Informasi Profil Kesehatan Indonesia 2016," 2016.

[6] Komisi Penanggulangan AIDS, "Semarang Utara Tertinggi HIV/AIDS," Radar Semarang, Semarang, 06-Apr-2015.

[7] K. Irianto, Kesehatan Reproduksi (Reproductive Health). Bandung: CV. Alfabeta, 2015.

[8] H. zan Pieters and N. L. Lubis, Pengantar Psikologi dalam Keperawatan, 1st ed. Jakarta: Kencana, 2017.

[9] Dinkes Kota Semarang, "Situasi HIV AIDS Kota Semarang Tahun 2018." Dinkes Kota Semarang, Semarang, p. 1, 2018.

[10] Y. Fauzi, P. C. B, K. Jamilah, M. Luthfi, and W. O. M. H, "Peran Kultur Lokalisasi dalam 
Perilaku Seksual Anak di Gang 3 Pasar Kembang Yogyakarta," 2013.

[11] Puskesmas Lebdosari, "Data VCT Puskesmas Lebdosari." Puskesmas Lebdosari, Semarang, 2018.

[12] M. H. Satari and F. F. Wirakusumah, Konsistensi Penelitian: dalam Bidang Kesehatan. Bandung: Refika Aditama, 2011.

[13] A. S. Sadiman, Media Pendidikan: Pengertian, Pengembangan, dan Pemanfaatannya. Depok: PT Raja Grafindo Persada, 2014.

[14] J. Hayden, Introduction to Health Behavior Theory. Burlington: Jones \& Burlet Learning, 2014.

[15] R. Wirdhayanthi, I. F. Ibnu, and M. Syafar, "Perilaku Pramusaji Café Terhadap Kesehatan Reproduksi Di Kabupaten
Pangkep," J. FKM Univ. Hasanuddin Makassar, pp. 1-14, 2014.

[16] O. Emilia, Y. S. Prabandari, and Supriyati, Promosi Kesehatan dalam Lingkup Kesehatan Reproduksi. Yogyakarta: Gadjah Mada University Press, 2019.

[17] C. Hao, J. Guida, D. E. Morisky, and H. Liu, "Family Network, Workplace Network, and Their Influence on Condom Use: A Qualitative Study among Older Female Sex Workers in China," J. Sex Res., vol. 52, no. 8, pp. 924-935, 2015, doi: 10.1080/00224499.2014.973101.

[18] A. Fatimah, "Persepsi Dan Perilaku Pekerja Seks Komersial Dalam Upaya Pencegahan Infeksi Menular Seksual Dan Hiv / Aids Di Kabupaten Bekasi Tahun 2017," 2017. 